\title{
An unusual modification of the jaws in cf. Alanqa, a mid-Cretaceous azhdarchid pterosaur from the Kem Kem beds of Morocco
}

\author{
David M. Martill*1 ${ }^{1}$ and Nizar Ibrahim ${ }^{2}$ \\ ${ }^{1}$ School of Earth and Environmental Sciences, University of Portsmouth, Portsmouth PO1 3QL, United \\ Kingdom \\ ${ }^{2}$ Department of Organismal Biology and Anatomy, University of Chicago, Chicago, IL 60637, United States \\ of America
}

\section{ABSTRACT}

A jaw bone attributed to the mid-Cretaceous azhdarchid pterosaur Alanqa saharica Ibrahim et al., 2010 is described. The new specimen from the Kem Kem beds of south eastern Morocco is unusual for the presence of expanded rostral bones that protrude above the occlusal surface of the jaws. The function of this unusual osteological modification is uncertain, but it is considered likely that it served a role in food processing, perhaps jaw stability.

\section{Keywords:}

Pterosauria, Azhdarchidae, Feeding, Cretaceous, Morocco

\section{Introduction}

Azhdarchid pterosaurs possessed highly elongate, slender, toothless jaws and have been regarded as stork or ground hornbill analogues in some terrestrial environments of the mid to Late Cretaceous (Witton, 2007; Witton and Naish, 2008). Some azhdarchid taxa achieved gigantic proportions with wing span estimated to be between 9 and 11 metres (Lawson, 1975; Frey and Martill, 1996; Witton, 2007; Witton and Habib, 2010). Their remains have been reported from Europe (Hungary Bakonydraco (found to be a tapejarid in the phylogenetic analysis of Andres and Myers [2013]; Romania Hatzegopteryx, and its junior synonym Eurazhdarcho; France, Spain and 
Russia, indeterminate remains;) the Middle East (Arambourgiania), Central Asia (Azhdarcho, Aralazhdarcho, Volgadraco), China (Zhejiangopterus), North America (Montanazhdarcho, Quetzalcoatlus), and North Africa (Alanqa, Phosphatodraco), where they range from as early as the Cenomanian to the Late Maastrichtian. Only Alanqa, Aralazhdarcho, Azhdarcho, Bakonydraco, Hatzegopteryx, Quetzalcoatlus and Zhejiangopterus have been reported with cranial remains (Table 1). In most cases these cranial are fragmentary jaw tips, and in some case it has proven difficult to distinguish between upper and lower jaw. The skull of Zhejiangopterus is known from a complete, but laterally crushed example but it has not been described in detail (Lü and Unwin, 1997). Similarly, a partial skull and mandible has been described for Quetzalcoatlus sp. (Kellner and Langstone, 1996) and a partial posterior skull is known for Hatzegopteryx (Buffetaut et al., 2002). Only rostral fragments are known for Alanqa, Aralazhdarcho, Azhdarcho and Bakonydraco.

The group is largely characterised by possessing highly elongate necks achieved by hyper elongation of some of the cervical vertebrae (most notably cv III to cv VI: Averianov, 2013; Frey and Martill, 1996; Ösi et al., 2005), elongate skulls with a generally slender mandible and wings with a highly shortened terminal phalange (Witton, 2013). Here we describe a new partial jaw of cf. Alanqa saharica that displays bony protuberances on the occlusal surface, and consider their function in terms of feeding and other roles.

Museum abbreviations. BSP, Bayerische Staatssammlung für Paläontologie und Geologie, Munich, Germany; FSAC, Faculté des Sciences Aïn Chock, Université Hassan II, Casablanca, Morocco.

\section{Context}

The specimen described here (FSAC-KK 4000) was discovered by a local collector on the flanks of an escarpment of Cretaceous strata south east of the small oasis community of Hassi El Begaa, near Taouz, Er Rachidia Province in south-eastern Morocco (Fig 1.). Here the fluvio-lacustrine Kem Kem beds of mid Cretaceous age rest unconformably on folded Palaeozoic strata and are overlain by transgressive marine carbonates of middle Cenomanian age (Fig. 2.) (Martill et al., 2011). Certain horizons within the Kem Kem beds at this locality are rich in isolated, and occasionally associated vertebrate remains, including the elasmobranchs Onchopristis and Asteracanthus, bony fishes (the coelacanth cf. Mawsonia, Lepidotes sp., the lungfish Ceratodus), crocodilians, dinosaurs (e.g. Spinosaurus, Carcharodontosaurus, Rebbachisaurus) and pterosaurs (Alanqa and an indeterminate ornithocheirid). The vertebrate assemblage from this locality and several nearby sites has been described by Lavocat (1954), Sereno et al. (1996), Dutheil (1999), Gaffney et al. (2006), Ibrahim, Varricchio et al. (2014), Ibrahim, Sereno et al. (2014) and Cavin et al. (2010), and several 
authors have reported pterosaur remains (Wellnhofer and Buffetaut, 1999; Ibrahim et al., 2010; Rodrigues et al., 2011).

\section{Systematic palaeontology and description}

\subsection{Systematics.}

Pterosauria Kaup, 1834

Pterodactyloidea Plieninger, 1901

Azhdarchoidea Unwin, 1992

Azhdarchidae Nessov, 1984 (emend. Padian, 1986)

cf. Alanqa saharica Ibrahim et al., 2010

Material: The specimen described here is a single portion of symphysial mandible accessioned to the collection of the University of Casablanca No. FSAC-KK 4000.

Horizon and stage: Kem Kem beds, Hassi El Begaa, Er Rachidia Province, south-eastern Morocco; mid-Cretaceous (probably Albian to lower Cenomanian).

Locality: Aferdou N'Chaft mesa, near Hassi Er Begaa, Er Rachidia Province, Morocco. 30 53 ' $59.33 " \mathrm{~N} \quad 3^{\circ} 50$ ’ 44.91” W. Elevation $790 \mathrm{~m}$.

\subsection{Description.}

General: Specimen FSAC-KK 4000 is a portion of jaw $157 \mathrm{~mm}$ long with broken ends both anteriorly and posteriorly (Fig. 3). It displays an occlusal surface with a shallow median sulcus between prominent, gently tapered, straight and even lateral margins. The broken areas of the specimen reveal an internal arrangement of trabeculae that are sparsely distributed anteriorly, but much more dense and complex posteriorly. The broken surfaces also show some post-mortem wear. The bone is grey to pale grey and has a few patches of adherent, red to pink sandy matrix attached. Posteriorly there are paired, elongate tapered protuberances that extend from a position exterior to the lateral margins of the jaw posteriorly and extend toward the median line of the occlusal surface of the jaw. They do not meet in the middle, but taper to a point that then becomes flush with the occlusal surface defining faint sutures that meet in the midline (Fig. 3). The bone is thin $(1 \mathrm{~mm}$ to $1.5 \mathrm{~mm}$ ), and consistent with a pterosaurian affinity for the specimen (other measurements are given in Table 2). Much of the bone is lightly abraded with the fibrous internal texture beneath smooth endosteal bone exposed. There is some micro-pitting due to pressure solution by compacted quartz grains. 
Occlusal surface. The occlusal surface is concave, smooth and lacks any midline structure for all of its length from the anterior most position until a point anterior to the pair of elongate protuberances noted above. At this point the sulcus deepens as it passes between the protuberances, but laterally rises until it 'wraps' laterally around the protuberance on each side, becoming confluent with the jaw margin. At the posterior most position the sulcus is confluent with the medial margins of the protuberances. A faint suture is visible extending anteriorly to the mid-line from the anterior termination of the protuberances (Figs. 3E, 4A), and is seen more clearly in oblique view (Fig. 3E$\mathrm{G})$. The exposed internal vacuity reveals a flattened internal surface of the occluding part of the jaw posteriorly becoming concave anteriorly.

Lateral margins. The lateral margins of the jaw are preserved to a maximum height of $9 \mathrm{~mm}$. The margins are straight, sub-parallel, tapering anteriorly and estimated to converge to a sharp point approximately $330 \mathrm{~mm}$ in front of the broken anterior margin. The lateral wall of the jaw is thickened at the boundary between the lateral margins and the occlusal surface (Fig. 4D), producing a sloping buttress with the occlusal surface in some places, more noticeable on the anterior left medial surface. The edge of the preserved portion of the lateral margins is worn, and there is no convincing evidence for the margin of the nasoantorbital fenestra.

Internal trabeculae. The broken internal vacuity exposes the internal trabeculae where they are attached to the base of the lateral margins and the internal occlusal surface. Anteriorly the trabeculae are simple, forming a series of short, thin projections extending at approximately $90^{\circ}$ from the internal surface of the lateral margins of the jaw, but in only one case reaching the midline to form a bridge across the jaw. They are regularly spaced for a length of approximately $100 \mathrm{~mm}$ and separated from adjacent trabeculae by an average of $7.5 \mathrm{~mm}$ on the left side. Some of the trabeculae have a corresponding trabeculum on the other side, but the pairing is not complete (Figs. 3B, 4B). Posteriorly the trabeculae adopt a different pattern. From a point $50 \mathrm{~mm}$ from the posterior margin the trabeculae are more densely distributed, and form a network of interconnected branches that on average radiate from the internal surface of the lateral margins at $45^{\circ}$. Some of these trabeculae are sheet like (Fig. 4B), but some are thin rods, and at least one is a thin hollow tube.

Dimensions. The portion of rotrum has a maximum length of $157 \mathrm{~mm}$ with a posterior width of 21 $\mathrm{mm}$ tapering gently to $16.5 \mathrm{~mm}$ anteriorly (Table 2). Extension of the lateral margins anteriorly to a point indicates that some $330 \mathrm{~mm}$ is missing, giving the rostrum a total length of $487 \mathrm{~mm}$ from the beginning of the lateral protuberances. The margins converge at an angle of $\sim 3^{\circ}$. As no examples of Alanqa jaws are known behind this point, it is not possible to estimate the precise length of the skull when complete. The dentary of Quetzalcoatlus sp. a slender-beaked azhdarchid pterosaur from the Upper Cretaceous of Texas described by Kellner and Langston (1996) is reconstructed at 
up to $960 \mathrm{~mm}$, with the mandibular symphysis occupying some $60 \%$ of the lower jaw. Ibrahim et al. (2010) estimated a minimum length for symphysial dentary of Alanqa saharica holotype of at least $424 \mathrm{~mm}$ by comparisons with this taxon. Clearly Alanqa saharica had an extremely elongate and slender skull as does FSAC-KK 4000.

\section{Discussion}

\subsection{Upper or lower jaw?}

Because both the lower and upper jaws of azhdarchid pterosaurs are long and slender, anteriorly approximating to mirror images of each other, at least in the anterior most portion of the rostrum, determining between upper and lower jaws for fragmentary specimens can be problematic. The anterior rostrum of mature individuals within pterodactyloid pterosaurs rarely displays distinctive sutures between the premaxillae, maxillae and palatines and other elements of the palate. Similarly, the configuration of the various elements that comprise the mandible is rarely discernable. Furthermore, the degree of expansion seen in lateral view of the dorsal rostrum or ventral surface of the mandible may not be sufficient to distinguish between these skull components. In the azhdarchoid Tapejara wellnhoferi the dentary possesses a descending median crest that, in isolation, might be mistaken for the rising antero-dorsal border of the premaxilla of (e.g.) Tupuxиara (see for example comments by Wellnhofer and Buffetaut, 1999, p. 137). The jaws attributed to an azhdarchid pterosaur from the Kem Kem beds of Morocco have been described by Wellnhofer and Buffetaut (1999) and by Ibrahim et al. (2010), the latter authors erecting the taxon Alanqa saharica for their reception. The anterior jaw fragment figured by Wellnhofer and Buffetaut (1999, fig. 5, BSP 1996 I 36) was identified as a premaxilla, whereas a remarkably similar, but somewhat longer specimen described by Ibrahim et al. (2010, figs. 2-3, FSAC-KK 26 holotype of A. saharica) was considered to be a mandible. Neither specimen displays mandibular rami or palatal fenestrae, making identifications reliant on subtle, and not necessarily wellunderstood features. In the case of BSP 1996 I 36 the occluding surface is a shallow sulcus with a midline raised ridge becoming subtly more prominent posteriorly. The occluding surface of FSACKK 26 is similarly a shallow sulcus, but it has a somewhat flatter and slightly less prominent ridge developed posteriorly, but the differences are remarkably slight. In addition, the holotype of $A$. saharica has a mid-line eminence at its most posterior point. This is not seen in BSP 1996 I 36, but this is most likely because this specimen does not overlap with FSAC-KK 26 (see Fig. 3 I). The extremely low lateral profile of both BSP 1996 I 36 and FSAC-KK 26 in the authors opinion, hints more towards a rostral identification of these two specimens. The specimen described here (FSACKK 4000) with the protuberances located either side of the occluding jaw margin overlaps (in terms of length) with the holotype of $A$. saharica with its mid-line eminence locating in a similar position posteriorly to protuberances. Thus the new specimen may be the counter surface to the mandible of 
A. saharica (but we do not imply it is from the same individual) and is thus likely a portion of the rostrum. In which case, the lateral protuberances present on FSAC-KK 4000 most likely represent ventral projections of the lateral margins of either the palatines just posterior to the maxillae, part of the maxillary shelf just posterior to the premaxillae, or perhaps anterior most parts of splenials.

\subsection{Affinities}

Apart from the presence of the two enigmatic elongate lateral protuberances, in all other respects FSAC-KK 4000 appears to represent a portion of the rostrum of a pterosaur jaw. Indicators include the elongate nature of the element and the extremely thin bony wall. The narrow profile of the jaw in dorsal and ventral view is not seen in any other Kem Kem vertebrate. A lack of dental alveoli suggests affinities with either Azhdarchoidea or Pteranodontidae + Nyctosauridae (sensu Unwin, 2003 and Lü et al., 2010), both edentulous pterosaurs with elongate jaws. A pteranodontid or nyctosaurid identification, while possible, is ruled out on account of both morphological grounds and geological context. To date, all confirmed occurrences of pteranodontid and nyctosaurid pterosaurs have been from fully marine strata (Bennett, 1994, 2003; Williston, 1903; Frey et al., 2006). Furthermore, a possible pterandontid jaw fragment from the fluvial Kem Kem beds described by Wellnhofer and Buffetaut (1999) was reidentified as an azhdarchid mandibular symphysis by Averianov et al. (2008), a view accepted by Vullo and Neraudeau (2009) but suggested to be an azhdarchid anterior rostrum by Ibrahim et al. (2010). The jaws of chaoyangopterids are also edentulous but are not well known in 3D and therefore difficult to analyse in detail. Chaoyangopterus Wang and Zhou (2003) has a relatively short rostrum that, it is assumed, cannot be as slender as that of the specimen described here. Jidapterus Dong et. al. (2003) and Lacusovagus Witton (2008) do possess a slender rostrum, but there are no protuberences on either the mandible or rostrum in Jidapterus or the rostrum of Lacusovagus. Azhdarchid jaw fragments can be distinguished from those of pteranodontids and nyctosaurids by the presence of elongate, slit-like perforation on the lateral walls of the jaws and on the palatal surface of the rostrum or symphysial shelf of the mandible (Ibrahim et al., 2010). However, this feature is somewhat variable among the different azhdarchid genera (e.g. see Bakonydrako Ösi et al., 2005 and Volgadraco Averianov et al., 2008. Compare also a jaw tip assigned to Azhdarcho lanciocollis by Nessov (1984) and that figured by Averianov (2010), and is usually much better developed anteriorly. Thus the holotype of Alanqa saharica which lacks the anterior most part of the mandibular symphysis displays only two or three of these slits at the most anterior part of the specimen (Ibrahim et al., 2010, fig. 3). These slits are mostly absent on FSAC- KK 4000, perhaps on the lateral margins because so little of them is preserved, but only one can be detected on the occlusal surface with confidence. This single slit-like foramen is present anteriorly slightly left of the midline and has an antero-lateral trajectory (Figs. 3A, 4A). The general lack of these slit-like foramina may be because of the more posterior location of the fragment compared to other 
specimens known for Alanqa. The occluding surface of the jaws of Nyctosaurus, Pteranodon and possibly Muzquixopteryx are gently curved (Bennett, 1994, 2003; Frey et al., 2006) rather than the straight condition seen in Alanqa and several other azhdarchids, but not Bakonydraco (Ösi et al., 2005), which might be a tapejarid (Andres and Myers 2013). Thus, the level margin of the occluding surface and the presence of a single slit-like foramen on the occluding surface suggest azhdarchid affinities. The stratigraphic horizon and the location strongly suggest that FSAC- KK 4000 should be referred to Alanqa saharica. This identification is consistent with our knowledge of azhdarchid jaws. The jaws of Alanqa, in particular, are remarkably straight and narrow.

\subsection{Function of the lateral protuberances}

A functional role integral to the autecology of Alanqa saharica is considered highly likely for the protuberances on the jaw. A pathological origin is ruled out on the grounds of a second specimen offered for sale a few years ago and present whereabouts unknown (Fig. 5). FSAC- KK 4000 is unusual for the presence of paired expanded protuberances that extend above the jaw line. No such structure has been reported for Pterosauria, and neither has any analogous structure been reported for the jaws of extant birds. Bony protuberances do occur however in the Odontopterygiformes of the late Paleocene to Pliocene/Pleistocene where tooth-like margins are developed on the mandible and premaxilla (Bourdon, 2005). Some birds do possess protuberances on the margins of the rhamphotheca, notably hornbills (Bucerotidae) which might function in a similar fashion, and certainly interfere with full closure of the jaws (Fig. 6). There is a dorsal expansion of the jaw margin in the mandible of Bakonydraco, with a transverse ridge between the summit of the expansion, but it is not known if it corresponds with a notch on the rostrum (Ösi et al., 2005), and this feature looks very different from that seen in FSAC- KK 4000. Particularly odd is that the protuberances of FSAC- KK 4000 would appear to interfere with the full closure of the jaws, should the rhamphotheca or other soft tissue covering of the bone be of negligible thickness. The exposed internal surface of the palate reveals extensive modification of the internal trabecular framework in the vicinity of the protuberance and would considerably strengthen this region of the skull (Fig. 3B, H, 4B). The robust appearance of the protuberances, their rounded cross-sectional profile, thickened bone and their position apparently opposite a median eminence in the mandible of Alanqa saharica described by Ibrahim et al. (2010) suggests a tritorial function in feeding. Occlusion of the jaws would allow the median eminence of the lower jaw to insert between the two lateral protuberances of the upper jaw, with any food item in between firmly crushed. Perhaps another function for the protuberances could be for anchoring soft tissues forming cheeks or elaborate display structures, although these suggestions are entirely speculative (Fig. 7).

\section{Conclusions}


Alanqa saharica was an azhdarchid pterosaur with a jaw possibly modified for crushing hard prey. Such a conclusion regarding the diet of this pterosaur is not entirely inconsistent with the conclusion of Witton and Naish (2008) who regarded azhdarchids as animals foraging for live animals and carrion in the manner of storks and ground hornbills. Probe feeding for molluscs and other invertebrates was proposed as a feeding strategy by Lehman and Langston (1996), but ruled out by Martill (1997) and Witton and Naish (2008) on account of the inflexibility of the long neck and the cross sectional shape of the rostrum.

The Kem Kem beds have yielded a diverse fossil assemblage, but it is dominated almost entirely by vertebrates. Evidence for invertebrates in the Kem Kem beds is restricted to trace fossils of Beaconites and Conichnus type (Ibrahim et al. 2014) while very rare unionid bivalves at Begaa, and decapod crustaceans from Oum Tkiout have been reported (Ibrahim 2014 In press). Thus, a generalist feeder with a similar mode of foraging to living storks might select a diet of both invertebrates and small vertebrates. An ability to crush the shells of molluscs and crustaceans, and perhaps vertebrates such as turtles, would seem to be an advantage.

\section{Acknowledgements}

Thanks to Samir Zouhri, Alex Srdic, Claire Bullar and James Brown for assistance in Morocco. DMM thanks the University of Portsmouth and in particular Professor Rob Strachan for supporting this research. We had thoughtful conversations with Mark Witton, Michael O'Sullivan and Steve Vidovic, with special thanks to Mr Frédéric Weber for providing information and photographs of specimens currently in private collections. Oliver Rauhut of Bayerische Staatssammlung für Paläontologie und historische Geologie, München, Germany, and Lorna Steel of the Natural History Museum, London are thanked for access to specimens in their care. Thanks go to Attila Ösi and an anonymous referee who greatly improved the paper.

\section{References}

Andres, B., Myers, T.S., 2013. Lone star pterosaurs. Earth and Environmental Science Transactions of the Royal Society of Edinburgh, Available on CJO 2013 doi:10.1017/S1755691013000303

Arambourg, C., 1959. Titanopteryx philadelphiae, nov. gen. nov. sp. ptérosaurien géant. Notes de Mémoir Moyen Orient 7, 229-234.

Averionov, A.O., 2007. New records of azhdarchids (Pterosauria, Azhdarchidae) from the Late Cretaceous of Russia, Kazakhstan, and Central Asia. Paleontological Journal 41, 189-197. 
Averianov, A.O., 2010. The osteology of Azhdarcho lancicollis Nessov, 1984 (Pterosauria, Azhdarchidae) from the Late Cretaceous of Uzbekistan. Proceedings of the Zooogical Institute of the Russian Academy of Science 314, 264-317.

Averianov, A.O., 2013. Reconstruction of the neck of Azhdarcho lancicollis and lifestyle of azhdarchids (Pterosauria, Azhdarchidae). Paleontological Journal 47, 203-209.

Averianov, A.O., Arkhangelsky, M. S., Pervushov, E. M., Ivanov, A. V., 2005. A new record of an azhdarchid (Pterosauria: Azhdarchidae) from the Upper Cretaceous of the Volga region. Paleontological Journal 39, 91-97.

Averianov A.O., Arkhangelsky M. S., Pervushov E. M., 2008. A new Late Cretaceous azhdarchid (Pterosauria, Azhdarchidae) from the Volga Region. Paleontological Journal 42, 634-642.

Bennett, S.C., 1994. Taxonomy and systematics of the Late Cretaceous pterosaur Pteranodon (Pterosauria, Pterodactyloidea). Occasional papers of the Natural History Museum, The University of Kansas 169, 1-70.

Bennett, S.C., 2003. New crested specimens of the Late Cretaceous pterosaur Nyctosaurus. Stuttgart. Paläontologische Zeitschrift 77, 61-75.

Bourdon, E., 2005. Osteological evidence for sister group relationship between pseudo-toothed birds (Aves: Odontopterygiformes) and waterfowls (Anseriformes). Naturwissenschaften 92, 586-591.

Buffetaut, E., Grigorescu, D., Csiki, Z., 2002. A new giant pterosaur with a robust skull from the latest Cretaceous of Romania. Naturwissenschaften 89, 180-180.

Buffetaut, E., Grigorescu, D., Csiki, Z., 2003. Giant azhdarchid pterosaurs from the terminal Cretaceous of Transylvania (western Romania). In: Buffetaut, E., Mazin, J.-M., (Eds.), Evolution and palaeobiology of pterosaurs. Geological Society of London Special Publications 217, 91-104.

Cavin, L., Tong, H., Boudad, L., Meister, C., Piuz, A., Tabouelle, J., Aarab, M., Amiot, R., Buffetaut, E., Dyke, G., Hua, S., Le Loeuff, J., 2010. Vertebrate assemblages from the early Late Cretaceous of southeastern Morocco: an overview. Journal of African Earth Sciences 57, $391-412$.

Company, J., Ruiz-Omeñaca, J.I., Pereda Suberbiola, X., 1999. A long-necked pterosaur (Pterodactyloidea, Azhdarchidae) from the Upper Cretaceous of Valencia. Geologie en Mijnbouw 78, 319-333.

Currie, P.J., Russell D.A., 1982. A giant pterosaur (Reptilia: Archosauria) from the Judith River (Oldman) Formation of Alberta. Canadian Journal of Earth Sciences 19, 894-897.

Dong, Z., Sun, Y., Wu, S., 2003. On a new pterosaur from the Lower Cretaceous of Chaoyang Basin, Western Liaoning, China. Global Geology 22, 1-7. 
Dutheil, D.B., 1999. An overview of the freshwater fish fauna from the Kem Kem beds (Late Cretaceous: Cenomanian) of southeastern Morocco. In Arratia, G., Schultze, H.-P., (Eds.). Mesozoic Fishes 2 - Systematics and the Fossil Record. 553-563.

Frey, E., Martill, D.M., 1996. A reappraisal of Arambourgiania (Pterosauria, Pterodactyloidea): one of the world's largest flying animals. Neues Jahrbuch für Geologie und Paläontologie Abhandlungen 199, 221-247.

Frey, E., Buchy, M.-C., Stinnesbeck, W., González, A.G., di Stefano, A., 2006, Muzquizopteryx coahuilensis n.g., n. sp., a nyctosaurid pterosaur with soft tissue preservation from the Coniacian (Late Cretaceous) of northeast Mexico (Coahuila). Oryctos 6, 19-39.

Gaffney, E.S., Tong, H., Meylan, P.A. 2006. Evolution of the side-necked turtles, the families Bothremydidae, Euraxemydidae, and Araripemydidae. Bulletin of the American Museum of Natural History 300, 1-698.

Ibrahim, N., Sereno, P.C., Dal Sasso, C., Maganuco, S., Fabbri, M., Martill, D.M., Zouhri, S., Myhrvold, N., Iurino, D.A., 2014. Semiaquatic adaptations in a giant predatory dinosaur. Science 345, 1613-1616.

Ibrahim, N., Varricchio, D.J., Sereno, P.C., Wilson J.A., Dutheil, D.B., Martill, D.M., Baidder, L., Zouhri, S., 2014. Dinosaur Footprints and other ichnofauna from the Cretaceous Kem Kem Beds of Morocco. PLoS ONE 9(3): e90751.

Ibrahim, N., Unwin, D.M. Martill, D.M., Baidder, L., Zouhri, S., 2010. A New Pterosaur (Pterodactyloidea: Azhdarchidae) from the Upper Cretaceous of Morocco. PLoS ONE 5(5): e10875.

Ibrahim, N., Varricchio, D.J., Sereno, P.C., Wilson, J.A., Dutheil, D.B., Martill, D.M., Baidder, L., Zouhri, S., 2014. Dinosaur footprints and other ichnofauna from the Cretaceous Kem Kem beds of Morocco. PLoS ONE 9(3): e90751.

Ibrahim, N., Sereno, P.C., Zouhri, S., 2014. Les dinosaures du Maroc - aperçu historique et travaux récents. Société géologique de France, (Mémoire). ISBN 2-85363-099-4.

Kaup, J., 1834. Versuch einer Eintheilung der Säugethiere in 6 Stämme und der Amphibien in 6 Ordnungen. Isis von Oken 1834, 311-324.

Kellner, A.W.A., Langston, W., 1996. Cranial remains of Quetzalcoatlus (Pterosauria, Azhdarchidae) from Late Cretaceous sediments of Big Bend National Park, Texas. Journal of Vertebrate Paleontology 16, 222-231.

Lavocat, R., 1954. Sur les dinosaures du Continental intercalaire des Kem-Kem de la Daoura. In: 19ème Congrès Géologique International, Alger, 1952, Comptes Rendus. Session XII-3 15. pp. 65-68.

Lawson, D.A., 1975. Pterosaur from the latest Cretaceous of west Texas. Discovery of the largest flying creature. Science 187, 947-948. 
Lehman, T.M., Langston, W. Jr., 1996. Habitat and behaviour of Quetzalcoatlus: paleoenvironmental reconstruction of the Javelina Formation (Upper Cretaceous), Big Bend National Park, Texas. Journal of Vertebrate Paleontology 16, 48A.

Lü, J., Unwin, D.M., 1997. On Zhejiangopterus and the relationships of pterodactyloid pterosaurs. Historical Biology 12, 199-210.

Lü, J., Unwin, D.M., Jin, X., Liu, Y., Ji, Q., 2010. Evidence for modular evolution in a long-tailed pterosaur with a pterodactyloid skull. Proceedings of the Royal Society B 277, 383-389.

Martill, D.M., 1997. From hypothesis to fact in a flight of fancy: the responsibility of the popular scientific media. Geology Today 13, 71-73.

Martill, D.M., Frey, E., Sadaqah, R.M., Khoury, H.N., 1998. Discovery of the holotype of the giant pterosaur Titanopteryx philadelphiae Arambourg, 1959 and the status of Arambourgiania and Quetzalcoatlus. Neues Jahrbuch für Geologie und Paläontologie Abhandlungen 207, 57-76.

Martill, D.M., Ibrahim, N., Brito, P.M., Baider, L., Zhouri, S., Loveridge, R., Naish, D., Hing, R., 2011. A new Plattenkalk Konservat Lagerstätte in the Upper Cretaceous of Gara Sbaa, southeastern Morocco. Cretaceous Research 32, 433-446.

McGowen, M.R., Padian, K., De Sosa, M.A., Harmon, R.J., 2002. Description of Montanazhdarcho minor, an azhdarchid pterosaur from the Two Medicine Formation (Campanian) of Montana. Paleobios 22, 1-9.

Monteillet, J., Lappartient, J.R., Taquet, P., 1982. Un pterosaurien géant dans le Crétacé Supérieur de Paki (Senegal). Comptes Rendus Academy des Sciences, Paris II 295, 409-414.

Nessov, L.A., 1984. Upper Cretaceous pterosaurs and birds from Central Asia [in Russian]. Paleontologičeskij Žurnal 1, 47-57.

Ösi, A., Weishampel, D.B., Jianu, C.M., 2005. First evidence of azhdarchid pterosaurs from the Late Cretaceous of Hungary. Acta Palaeontologica Polonica 50, 777-787.

Padian, K., 1986. A taxonomic note on two pterodactyloid families. Journal of Vertebrate Paleontology 6, 289.

Padian, K., Ricqlès, A.J., Horner, J.R., 1995. Bone histology determines identification of a new fossil taxon of pterosaur (Reptilia: Archosauria). Comptes Rendus de la Académie de Science du Paris, Series IIa 320, 77-84.

Pereda Suberbiola, X., Bardet, N., Jouve, S., Iarochéne, M., Bouya, B., Amaghzaz, M., 2003. A new azhdrachid pterosaur from the Late Cretaceous phosphates of Morocco. In: Buffetaut, E., Mazin, J.-M., (Eds.), Evolution and palaeobiology of pterosaurs. Geological Society of London Special Publications 217, 79-90.

Plieninger, F., 1901. Beiträge zur Kenntnis der Flugsaurier. Palaeontographica 48, 65-90.

Rodrigues, T., Kellner, A.W.A., Mader, B.J., Russell, D.A., 2011. New pterosaur specimens from the Kem Kem beds (Upper Cretaceous, Cenomanian) of Morocco. Rivista Italiana di Paleontologia e Stratigrafia 117, 149-160. 
Sereno, P.C., Dutheil, D.B., Iarochène, M., Larsson, H.C.E., Lyon, G.H, et al., 1996. Predatory dinosaurs from the Sahara and Late Cretaceous faunal differentiation. Science 272, 986-991.

Sullivan, R., Fowler, D.W., 2011. Navajodactylus boerei, n. gen., n. sp. (Pterosauria, ?Azhdarchidae) from the Upper Cretaceous Kirtland Formation (Upper Campanian) of New Mexico. Fossil Record 3. New Mexico Museum of Natural History and Science, Bulletin 53, 393-404.

Unwin, D.M., 1992. The phylogeny of the Pterosauria. Journal of Vertebrate Paleontology 12 (Supplement to No. 3), 57A.

Unwin, D.M., 2003. On the phylogeny and evolutionary history of pterosaurs. In: Buffetaut, E., Mazin, J.-M. (Eds.), Evolution and palaeobiology of pterosaurs. Geological Society, London, Special Publications 217, 139-190.

Unwin, D.M., Lü J., 1997. On Zhejiangopterus and the relationships of pterodactyloid pterosaurs. Historical Biology 12, 199-210.

Vremir, M. T. S., Kellner, A. W. A., Naish, D., Dyke, G. J., 2013. A new azhdarchid pterosaur from the Late Cretaceous of the Transylvanian Basin, Romania: implications for azhdarchid diversity and distribution. PLoS ONE 8: e54268. doi:10.1371/journal.pone.0054268

Vullo, R., Neraudeau, D., 2009. Pterosaur remains from the Cenomanian (Late Cretaceous) paralic deposits of Charentes, Western France. Journal of Vertebrate Paleontology 29, 277-282.

Wang, X., Zhou, Z., 2003. Two new pterodactyloid pterosaurs from the Early Cretaceous Jiufotang Formation of Western Liaoning, China. Vertebrata PalAsiatica 41, 34-41.

Wellnhofer, P., Buffetaut, E., 1999. Pterosaur remains from the Cretaceous of Morocco. Paläontologische Zeitschrift 73, 133-142.

Williston, S.W., 1903. On the osteology of Nyctosaurus (Nyctodactylus), with notes on American pterosaurs. Chicago, Field Columbian Museum, Publication 78, Geological Series 2(3), 125163.

Witton, M.P., 2007.Titans of the skies: azhdarchid pterosaurs, Geology Today 23, 33-38.

Witton, M.P., 2008. A new azhdarchoid pterosaur from the Crato Formation (Lower Cretaceous, Aptian?) of Brazil. Palaeontology, 51, 1289-1300.

Witton, M.P., 2013. Pterosaurs. Princeton University Press, 291 pp.

Witton, M.P., Habib, M.B., 2010. On the size and flight diversity of giant pterosaurs, the use of birds as pterosaur analogues and comments on pterosaur flightlessness. PLoS ONE 5(11): e13982. doi:10.1371/journal.pone.0013982

Witton, M.P., Naish, D., 2008. A reappraisal of azhdarchid pterosaur functional morphology and paleoecology, PLoS ONE 3, no. 5, p. e2271. 


\begin{tabular}{|c|c|c|c|c|c|}
\hline Azhdarchid taxa & Locality & $\begin{array}{l}\text { Cranial } \\
\text { remains }\end{array}$ & $\begin{array}{c}\text { Cervica } \\
1 \\
\text { vertebr } \\
\text { ae }\end{array}$ & $\begin{array}{l}\text { Other } \\
\text { remains }\end{array}$ & References \\
\hline Alanqa saharica & Morocco & $\mathrm{x}$ & $\mathrm{x}$ & & $\begin{array}{l}\text { Wellnhofer and Buffetaut, } 1999 \\
\text { Ibrahim et al., } 2010\end{array}$ \\
\hline Arambourgiania philadelphiae & Jordan & & $\mathrm{x}$ & $\mathrm{x}$ & $\begin{array}{l}\text { Arambourg 1959; Frey and Martill 1996; } \\
\text { Martill et al. } 1998\end{array}$ \\
\hline Aralazhdarcho bostobensis & Kazakhstan & & $\mathrm{x}$ & $\mathrm{x}$ & Averianov 2007 \\
\hline Azhdarcho lancicollis & Uzbekistan & $\mathrm{x}$ & $\mathrm{x}$ & $\mathrm{x}$ & Nessov 1984; Averianov 2010 \\
\hline Bakonydraco galaczi & Hungary & $\mathrm{x}$ & $\mathrm{x}$ & $\mathrm{x}$ & Ösi et al. 2005 \\
\hline Euroazhdarcho langendorfensis & Romania & & $\mathrm{x}$ & $\mathrm{x}$ & Vremir et al. 2013 \\
\hline Hatzegopteryx thambema & Romania & $\mathrm{x}$ & & $\mathrm{x}$ & Buffetaut et al. 2002, 2003 \\
\hline Montanazhdarcho minor & Montana & $\mathrm{x}$ & $\mathrm{x}$ & $\mathrm{x}$ & Padian et al. 1995; McGowen, et al. 2002 \\
\hline Navajodactylus boerei & New Mexico & & & $\mathrm{x}$ & Sullivan and Fowler 2011 \\
\hline Quetzalcoatlus northropi & Texas, & & & $\mathrm{x}$ & Lawson 1975 \\
\hline Quetzalcoatlus sp. & Texas, & $\mathrm{x}$ & $\mathrm{x}$ & $\mathrm{x}$ & Kellner and Langston 1996 \\
\hline Phosphatodraco mauritanicus & Morocco & & $\mathrm{x}$ & & Pereda Suberbiola et al. 2003 \\
\hline Volgadraco bogolubovi & Russia & $\mathrm{x}$ & $\mathrm{x}$ & $\mathrm{x}$ & Averianov 2005 \\
\hline Zhejiangopterus linhaiensis & China & $\mathrm{x}$ & $\mathrm{x}$ & $\mathrm{x}$ & Unwin and Lü 1997; Witton 2013 \\
\hline Indeterminate remains & $\begin{array}{l}\text { Canada } \\
\text { Spain } \\
\text { Senegal }\end{array}$ & & $\begin{array}{l}\mathrm{x} \\
\mathrm{x}\end{array}$ & $\mathrm{x}$ & $\begin{array}{l}\text { Currie and Russel } 1982 \\
\text { Company et al. } 1999 \\
\text { Montiellet et al. } 1982\end{array}$ \\
\hline
\end{tabular}

Table 1. Azhdarchid taxa with locality and skeletal parts documented. 


\begin{tabular}{|l|c|}
\hline \multicolumn{1}{|c|}{ Parameter } & Measurement \\
\hline Maximum length of segment & $157 \mathrm{~mm}$ \\
\hline Width proximally at external protuberance & $22 \mathrm{~mm}$ \\
\hline Width proximally at maxillary margins & $21 \mathrm{~mm}$ \\
\hline Width distally & $16.5 \mathrm{~mm}$ \\
\hline Length of protuberance & $43.5 \mathrm{~mm}$ \\
\hline Height of protuberances above jaw line & $5 \mathrm{~mm}$ \\
\hline Depth of sulcus at symphysis & $3.5 \mathrm{~mm}$ \\
\hline Bone thickness & $1 \mathrm{~mm}-1.5 \mathrm{~mm}$ \\
\hline
\end{tabular}

Table 2. Measurements for FSAC-KK 4000. 


\section{FIGURE CAPTIONS}

Figure 1. Map showing the area (X) where the new jaw FSAC-KK 4000 was recovered. Based on an overlay of images extracted from Google Earth. The approximate outcrop of the Kem Kem beds is indicated in dark grey. Areas to the west of the outcrop are Palaeozoic strata.

Figure 2. View of the Kem Kem Plateau escarpment near to Hasi El Begaa, south east Morocco with extensive outcrop of Kem Kem Beds on slope. The marine Akrabou Formation limestone of Cenomanian age forms the top of the plateau seen in the left of the picture. The lowest ground is made of coarse sands and rests unconformably on folded Palaeozoic basement not visible in this photograph. The vertebrate-bearing horizon forms a conspicuous line on the escarpment slope due to extensive digging for fossils by commercial operators.

Figure 3. Photographs of jaw fragment attributed to cf. Alanqa saharica Ibrahim et al., 2010, from the Kem Kem beds at Hassi El Begaa, south-eastern Morocco FSAC-KK 4000. A, New jaw fragment in occlusal view; B, internal surface of palate; $C$, right lateral view; $D$, detail of the maxillary protuberances in right lateral view, E, oblique lateral view of the maxillary protuberances; F, oblique anterior view of maxillary protuberances; G, oblique posterior view of maxillary protuberances; $\mathrm{H}$, detail of cross-cutting pattern of trabeculae on internal surface of palate above the maxillary protuberances, I, occlusal surface of mandibular symphysis fragment FSAC-KK 26 showing eminence that coincides with maxillary protuberances of FSAC-KK 4000 (after Ibrahim et al 2010). All scale bars $10 \mathrm{~mm}$.

Figure 4. Line drawings of cf. Alanqa saharica jaw fragment FSAC-KK 4000. A, occlusal view; B, view of interior surface of palate; C, left lateral view; D, outline of cross section at anterior end; E, schematic outline of rostrum interpreted to have been present in front of fragment; F, position of other elements attributed to Alanqa saharica and used to interpret FSAC-KK 4000.

Figure 5. A second specimen of cf. Alanqa saharica with protuberances on occlusal surface. The present whereabouts of this specimen is unknown. The provided image was of low resolution and lacked a scale bar.

Figure 6. Preserved specimen of hornbill (Abyssinian Ground Hornbill, Bucorvus abyssinicus) showing protuberances on rhamphothecae and inability to achieve full closure of jaws. Specimen on exhibition in Senkenberg Museum, Frankfurt. 
Figure 7. Possible functions of the protuberances on the rostrum of Alanqa saharica. A, as supports for a cheek; B, as visual markers for species recognition or mate attraction; $\mathrm{C}$, as surfaces on which hard shelled prey can be processed; D, as attachment areas for 'dewlap'-like skin growths. 


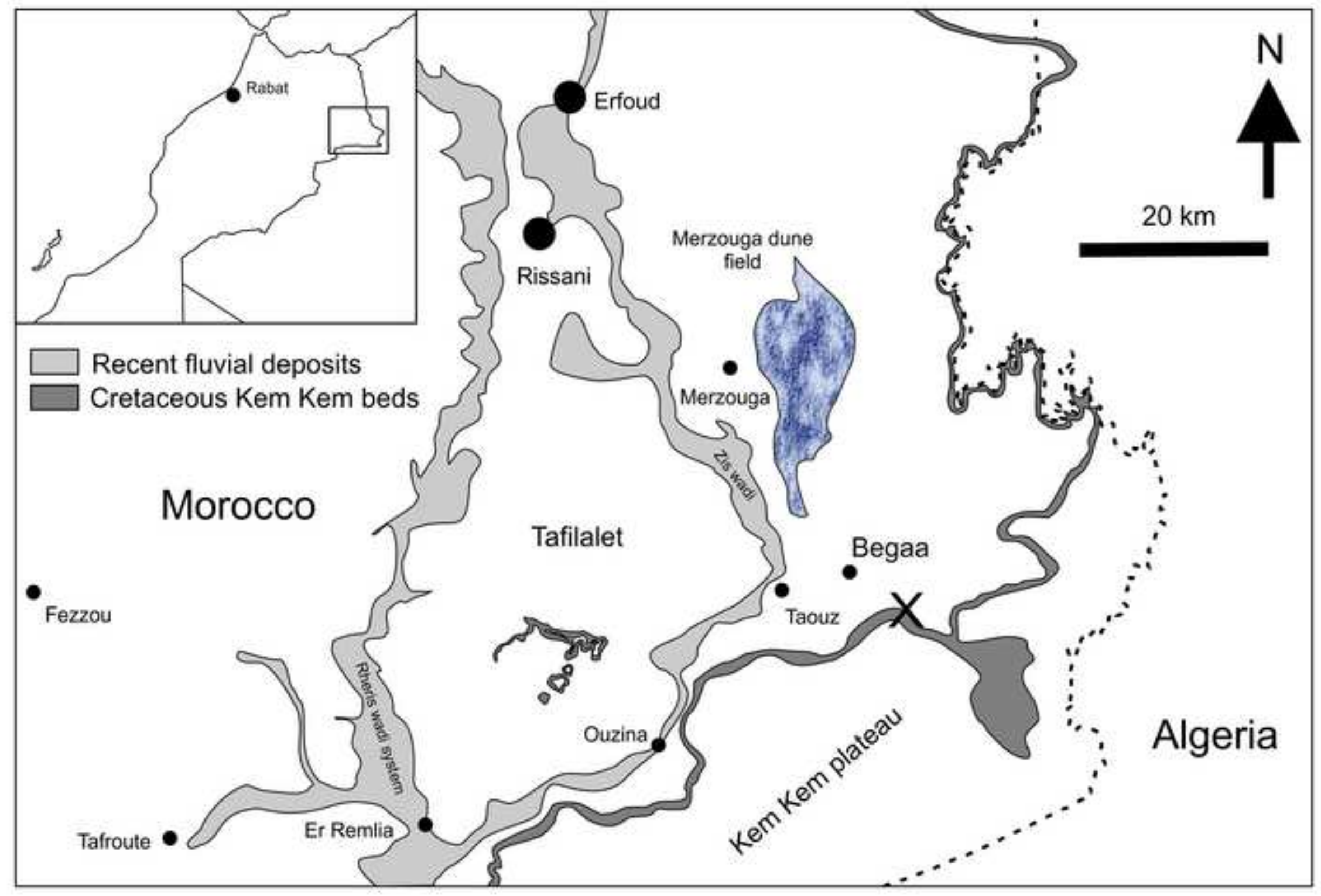




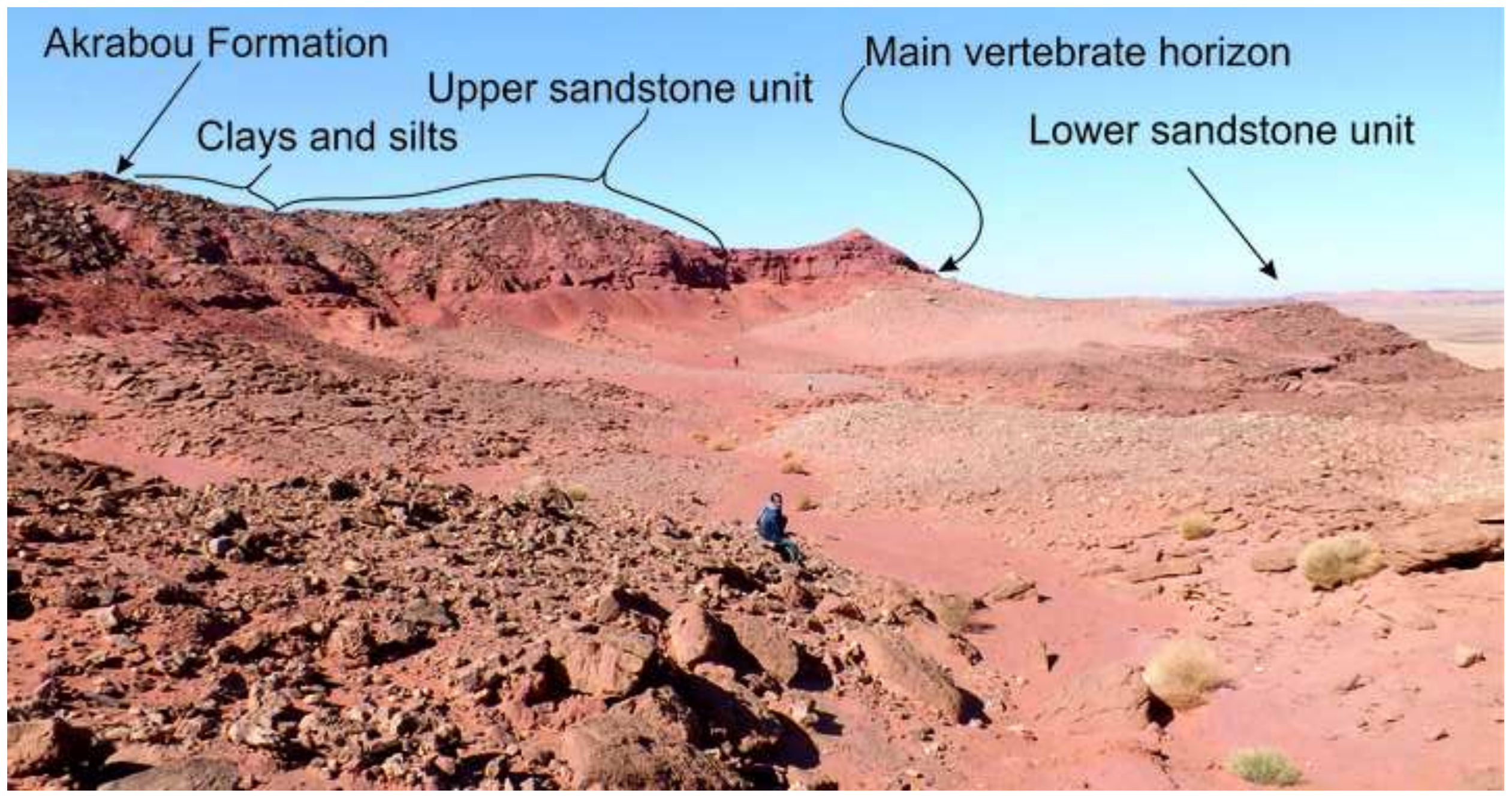




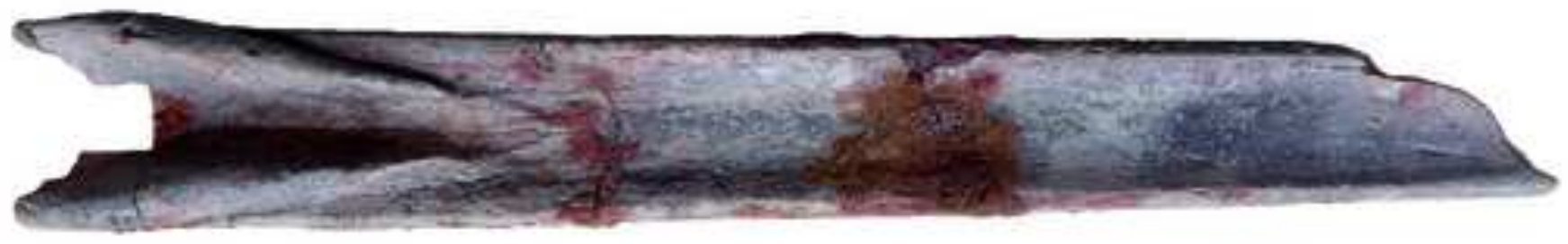

A
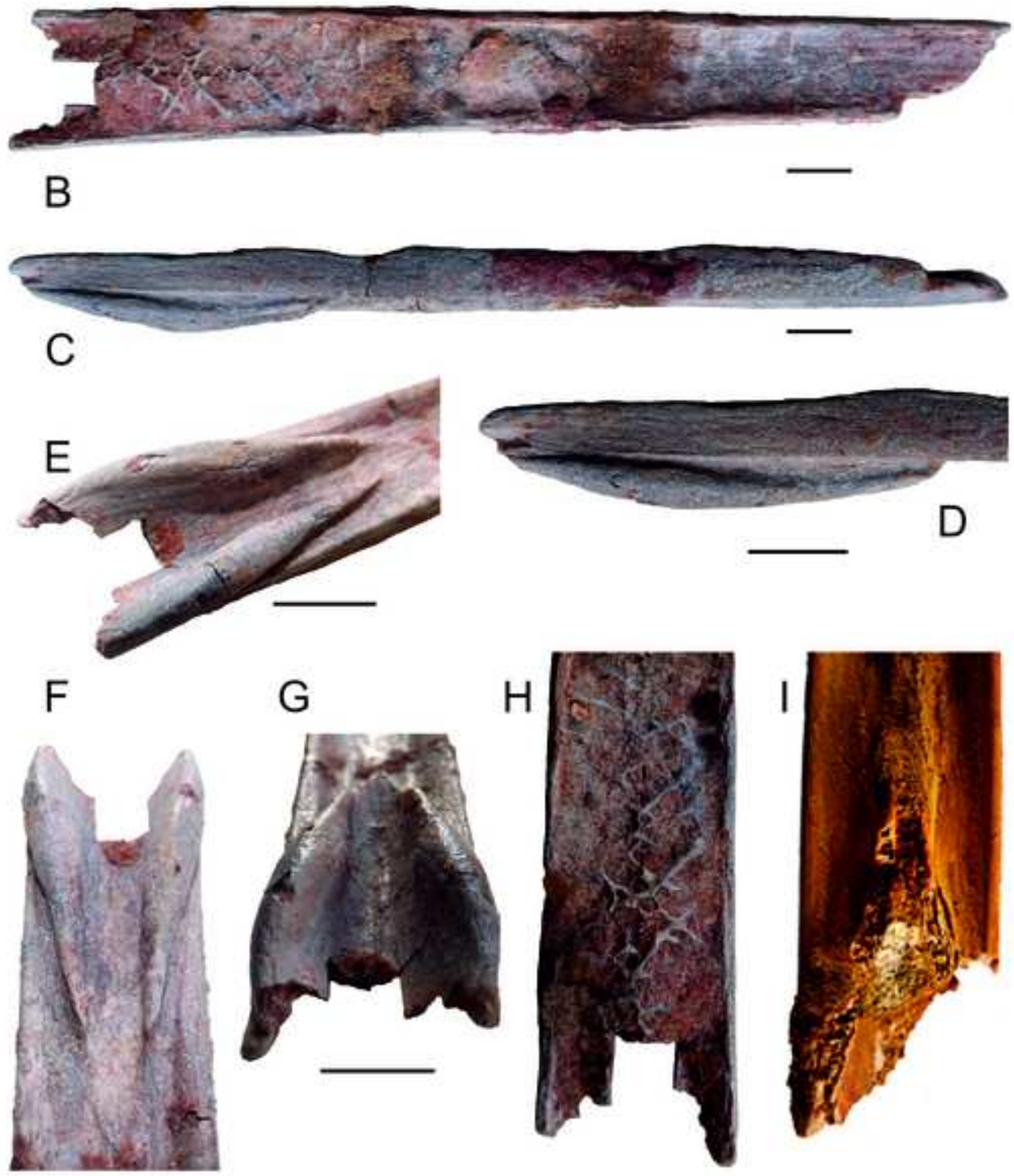

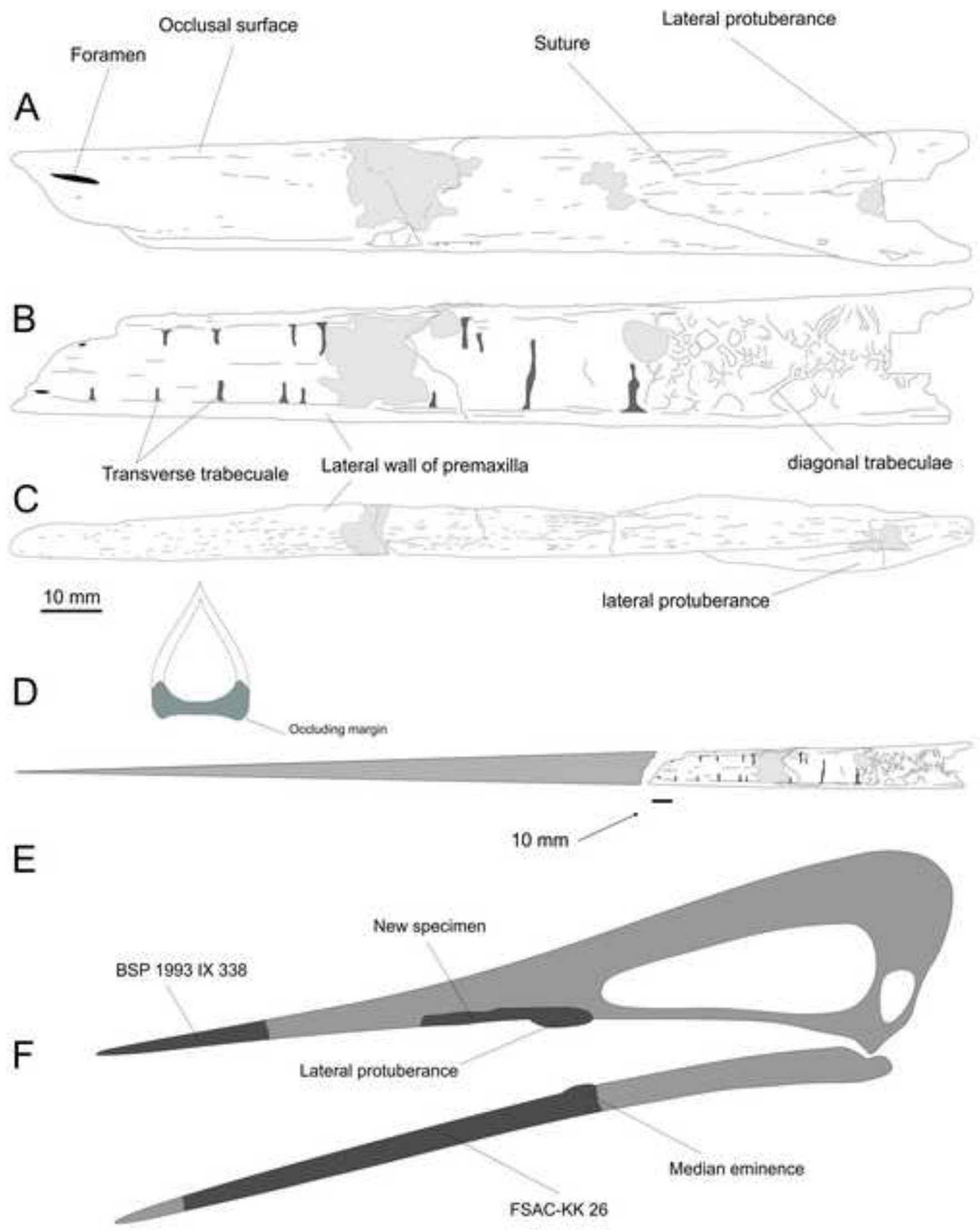


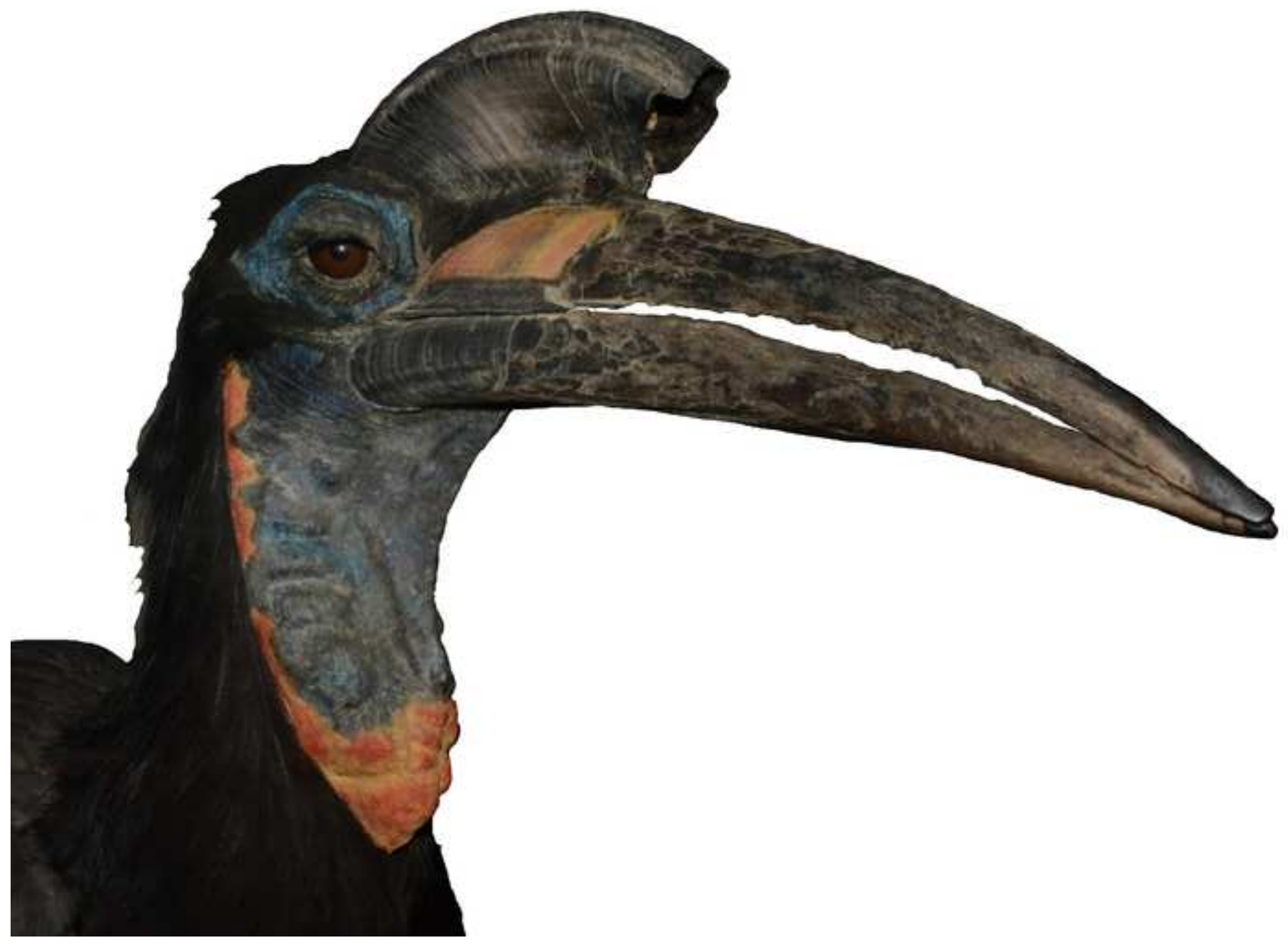




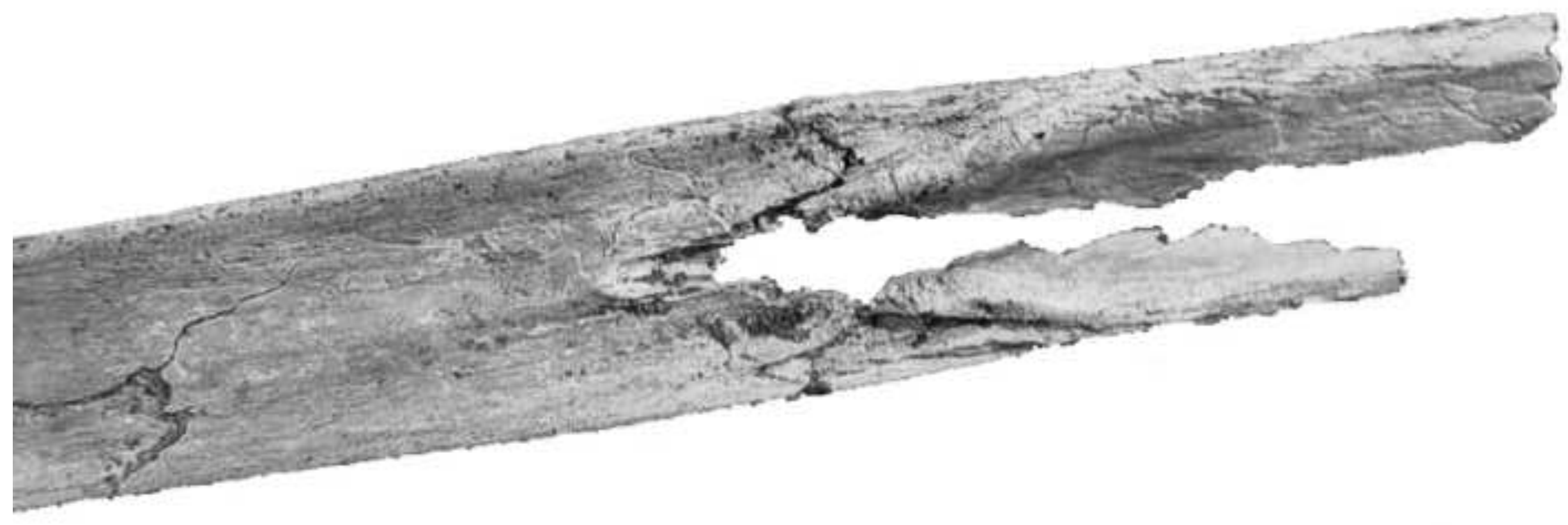



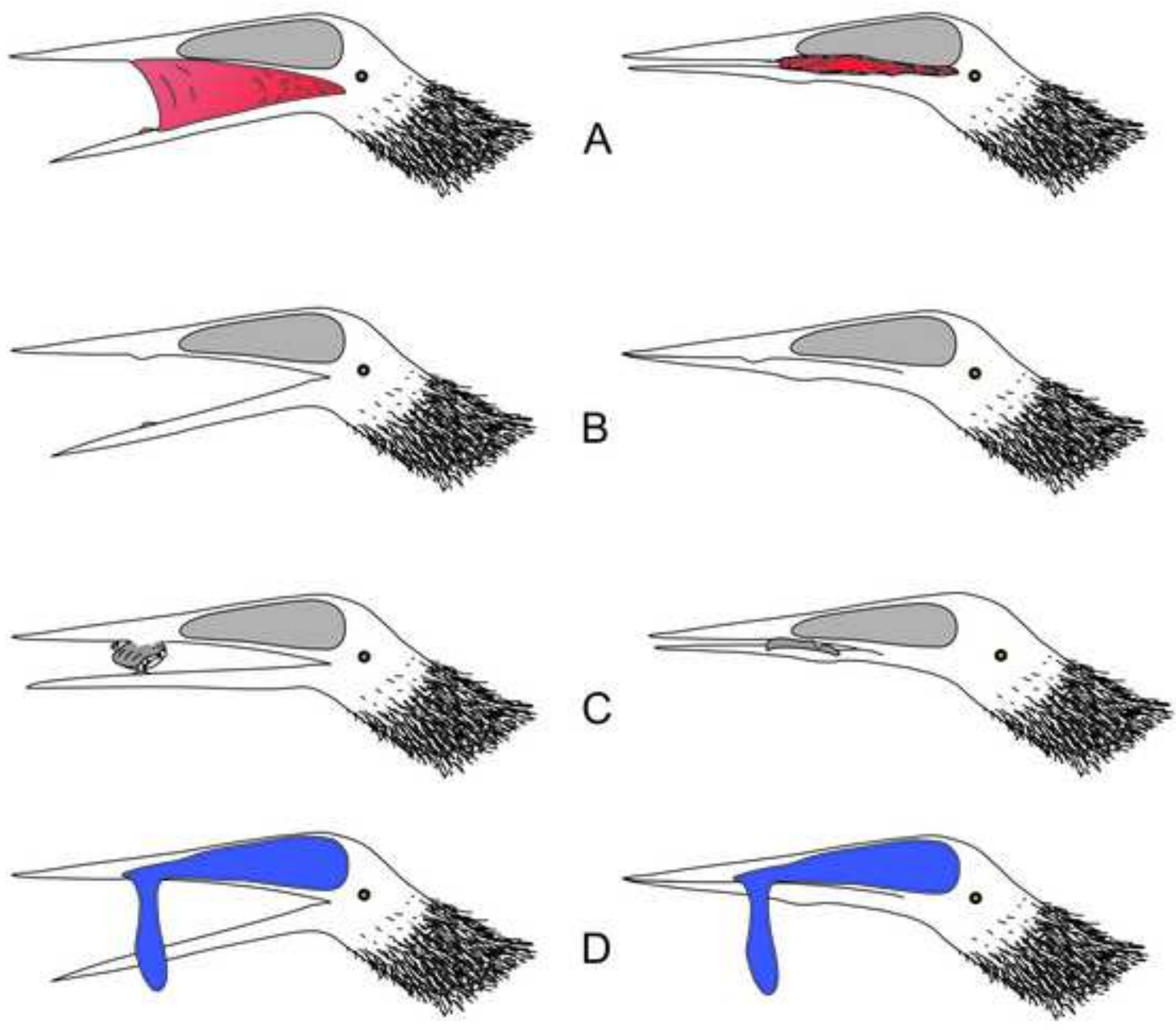